\title{
The Decomposition of $\mathrm{H}_{2} \mathrm{O}_{2}$ in Presence of Mixed Oxide Catalysts
}

\author{
By S. P. Walvekar and A. B. Halgeri
}

With 2 Figures

A bstract. The decomposition of $\mathrm{H}_{2} \mathrm{O}_{2}$ in presence of $\mathrm{TiO}_{2}-\mathrm{ZrO}_{2}$ (ignited to various temperatures), $\mathrm{SiO}_{2}-\mathrm{ZrO}_{2}, \mathrm{Al}_{2} \mathrm{O}_{3}-\mathrm{ThO}_{2}, \mathrm{SiO}_{2}-\mathrm{ThO}_{2}, \mathrm{Al}_{2} \mathrm{O}_{3}-\mathrm{MoO}_{3}, \mathrm{SiO}_{2}-\mathrm{MoO}_{3}, \mathrm{Al}_{2} \mathrm{O}_{3}-$ $\mathrm{WO}_{3}$ and $\mathrm{SiO}_{2}-\mathrm{WO}_{3}$ mixed oxide catalysts has been studied. As these catalysts are of bifunctional nature an attempt has been made to evaluate the decomposition brought about by acidic as well as by the basic sites by the poisoning technique. Both these sites catalyse the decomposition of $\mathrm{H}_{2} \mathrm{O}_{2}$. The energy of activation values $\mathrm{E}_{\mathrm{a}}$ and $\mathrm{E}_{\mathrm{b}}$ are inversely proportional to the acidity and basicity values. The mechanism of decomposition of $\mathrm{H}_{2} \mathrm{O}_{2}$ in presence of acidic and basic sites is of similar nature. Only acid sites having an acid strength in the range of $\mathrm{pKa}$ values $<+3.3$ and $>-3.0$ are able to catalyse the decomposition of $\mathrm{H}_{2} \mathrm{O}_{2}$. Basic centres which are strong as well as those which are moderately weak $(\mathrm{pKa} \geqq 10)$ are able to catalyse.

\section{Die Zersetzung von $\mathrm{H}_{2} \mathrm{O}_{2}$ in Gegenwart von Mischoxid-Katalysatoren}

Inhaltsübersicht. Es wird die Zersetzung von $\mathrm{H}_{2} \mathrm{O}_{2}$ in Gegenwart verschiedener Mischoxid-Katalysatoren (s. o.) untersucht. Da diese bifunktionell sind, wurde durch Inhibitoren versucht, die Wirkung der sauren und basischen Zentren getrennt zu messen. $K_{n}$, aufgetragen gegen die Säurestärke, und $K_{b}$, aufgetragen gegen die Basenstärke, ergaben. Geraden. Daraus wird geschlossen, daß beide Zentren die Zersetzung katalysieren. Die Werte der Aktivierungsenergien sind umgekehrt proportional den Säure- bzw. den BasenWerten. Der Zersetzungsmechanismus ist in beiden Fällen ähnlich. Zur Katalyse sind nur fähig Zentren mit Säurestärken von $\mathrm{pKa}<+3,3$ und $>-3$. Die basische Katalyse erstreckt sich von Zentren sehr starker bis mäßig schwacher Basizität ( $\mathrm{pKa} \geqq 10$ ).

\section{Introduction}

The study of the properties of mixed oxide catalysts has been undertaken by a large number of workers. In view of the usefulness of the decomposition of $\mathrm{H}_{2} \mathrm{O}_{2}$ to obtain information regarding the bifunctional behaviour of oxide catalysts, it was considered of interest to study this reaction with these catalysts for which no data exists.

An attempt has been made to evaluate the amount of decomposition brought about by the acidic sites as well as by the basic sites by the poisoning 
technique and also correlate these with the acidity, basicity and the energy of activation calculated from the kinetic data at different temperatures. The work on decomposition of $\mathrm{H}_{2} \mathrm{O}_{2}$ has been further extended to propose a mechanism based on the bifunctional behaviour of these catalysts and also to provide useful information regarding active acidic and basic centres present on the surface.

\section{Experimental}

Reagents. Merck's quality $\mathrm{H}_{2} \mathrm{O}_{2}$ which was purified by distillation at reduced pressure was used in this investigation. All other chemicals used in this investigation were pure quality chemicals.

Preparation of eatalysts. The mixed oxide catalysts were prepared by precipitation and impregnation technique ${ }^{1}$ ). The mixtures of the precipitated hydroxides and impregnated oxides were digested for several hours and then filtered, washed and dried at $120^{\circ} \mathrm{C}$ for 20 hours. The samples thus obtained were powdered and only such samples collected between 100 to 150 mesh sieves were preserved. The powders were subjected to heat treatment in the temperature range $120^{\circ} \mathrm{C}$ to $1000^{\circ} \mathrm{C}$ by heating the sample to the desired temperature for six hours in an electric muffle furnace with temperature control arrangement. The samples after heat treatment were cooled in a desiccator and preserved in glass tubes.

Measurement of surface acidity and basicity. The acidity of these mixed oxides were measured by amine titration method ${ }^{2}$ ) in benzene using p-dimethylaminoazobenzene ( $\mathrm{pKa}=+3.3$ ) and dicinnamal acetone ( $\mathrm{pKa}=-3.0$ ) as indicators. The surface basicity of these catalysts has been measured by the phenol adsorption method in benzene solution ${ }^{3}$.

Kinetic studies. $100 \mathrm{ml}$ of $0.2 \mathrm{M}$ solution of $\mathrm{H}_{2} \mathrm{O}_{2}$ in double distilled water and $1.0 \mathrm{~g}$ of mixed oxide catalyst were kept in flasks maintained at $30^{\circ} \mathrm{C}$ and $40^{\circ} \mathrm{C}$, in a thermostat, temperature variation being $\pm 0.01^{\circ} \mathrm{C}$. The $\mathrm{H}_{2} \mathrm{O}_{2}$ underwent decomposition in the presence of the acidic and basic centres on the surface of the catalyst. The amount of $\mathrm{H}_{2} \mathrm{O}_{2}$ that decomposed was estimated by titrating the undecomposed $\mathrm{H}_{2} \mathrm{O}_{2}$ against $0.01 \mathrm{M} \mathrm{KMnO}$ solution at regular intervals of time.

Experiments were carried out with samples of the catalyst that had been ignited for 6 hours at different temperatures in the range $120^{\circ} \mathrm{C}$ to $1000^{\circ} \mathrm{C}$.

Since the present catalysts have both acidic as well as basic sites on their surfaces and that both these sites catalyse the decomposition of $\mathrm{H}_{2} \mathrm{O}_{2}$, an attempt has been made to evaluate the amount of the decomposition brought about by the acidic as well as the basic centres. For this purpose the acidic sites were poisoned by neutral red and the catalyst used to evaluate the decomposotition by basic centres on the catalyst surface and similarly the basic centres were poisoned by $\mathrm{HCl}$ and the catalyst used to evaluate the decomposition by acidic centres on the catalyst surface $\left.{ }^{4}\right)$. Neutral red and $\mathrm{HCl}$ were selected for the purpose of

1) K. Shibata, T. KiYovra and K. Tanabe, J. Res. Inst. Catalysis, Hokkaido Univ; $18,189(1970)$.

2) O. Johnson, J. physic. Chem. 59, 827 (1955).

3) A. B. Halgeri, Ph. D. Thesis, Bangalore University, India (1972).

4) S. P. Walvekar and A. B. Halgeri, Paper presented to the Convention of Chemists, Bombay, India, p. 131 (1971). 
poisoning the acidic and the basic sites on the surface of the catalyst as these were found to have no effect on the decomposition of $\mathrm{H}_{2} \mathrm{O}_{2}$.

Since the decomposition of $\mathrm{H}_{2} \mathrm{O}_{2}$ is a very sensitive reaction ${ }^{5}$ ), the catalyst samples used were those which had the same acidic and basic properties throughout and were tested for their acidic and basic properties before the start of every decomposition reaction.

\section{Results and Discussion}

The values of $K$ (the rate constant for the catalyst as a whole), $K_{a}$ and $K_{b}$ (rate constants for the acidic and basic sites), the energy of activation values $\mathrm{E}_{\mathrm{a}}, \mathrm{E}_{\mathrm{b}}$ (for acidic and basic sites) were calculated from the initial slopes of the rate curves $\log (a-x) \rightarrow t$, which were straight lines. These values are presented in Tables 1 and 2.

Table 1 Decomposition of $\mathrm{H}_{2} \mathrm{O}_{2}$ in presence of $\mathrm{TiO}_{2}-\mathrm{ZrO}_{2}(68-32 \%)$ catalyst

\begin{tabular}{|c|c|c|c|c|c|c|c|c|c|c|c|}
\hline \multirow{4}{*}{$\begin{array}{c}\text { Sl. } \\
\text { No. } \\
1\end{array}$} & \multirow{4}{*}{$\begin{array}{c}\text { Tempe- } \\
\text { rature } \\
\text { of ignition } \\
{ }^{\circ} \mathrm{C} \\
2\end{array}$} & \multirow{4}{*}{$\begin{array}{c}\text { Acidity } \\
\text { m.moles/g } \\
\text { at } \\
\text { pKa }=3.3 \\
3\end{array}$} & \multirow{4}{*}{$\begin{array}{c}\text { Basicity } \\
\text { m.moles/g } \\
4\end{array}$} & \multicolumn{6}{|c|}{ Rate constant, hr ${ }^{-1}$} & \multirow{4}{*}{$\begin{array}{c}\mathbf{E}_{\mathbf{2}} \\
\text { calories } \\
\text { per mole } \\
11\end{array}$} & \multirow{4}{*}{ 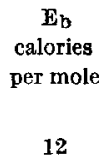 } \\
\hline & & & & \multicolumn{2}{|c|}{$\mathrm{K} \cdot 10^{2} \mathrm{at}$} & \multicolumn{2}{|c|}{$\mathbf{K}_{\mathrm{a}} \cdot 10^{2} \mathbf{a t}$} & \multicolumn{2}{|c|}{$\mathbf{K}_{\mathbf{b}} \cdot 10^{2}$ at } & & \\
\hline & & & & $30^{\circ} \mathrm{C}$ & $40^{\circ} \mathrm{C}$ & $30^{\circ} \mathrm{C}$ & $40^{\circ} \mathrm{C}$ & $30^{\circ} \mathrm{C}$ & $40^{\circ} \mathrm{C}$ & & \\
\hline & & & & 5 & 6 & 7 & 8 & 9 & 10 & & \\
\hline 1 & 120 & 0.11 & 0.60 & 20.0 & 31.0 & 3.1 & 6.1 & 16.0 & 25.0 & 12860 & 8420 \\
\hline 2 & 220 & 0.16 & 0.50 & 18.2 & 29.0 & 4.0 & 8.0 & 13.6 & 21.5 & 11760 & 8680 \\
\hline 3 & 360 & 0.20 & 0.26 & 10.3 & 19.0 & 5.2 & 8.6 & 6.9 & 11.5 & 9570 & 9680 \\
\hline 4 & 440 & 0.11 & 0.19 & 9.2 & 13.9 & 2.9 & 5.6 & 5.1 & 8.6 & 12430 & 9900 \\
\hline 5 & 520 & 0.12 & 0.15 & 7.8 & 11.0 & 2.9 & 5.7 & 4.6 & 7.9 & 12400 & 10240 \\
\hline 6 & 600 & 0.10 & 0.11 & 6.2 & 9.2 & 2.1 & 4.2 & 3.0 & 5.8 & 13140 & 12490 \\
\hline 7 & 700 & 0.02 & 0.08 & 3.5 & 6.0 & & & $\operatorname{Re}$ & ctions & too slow & \\
\hline 8 & 800 & 0.02 & 0.03 & 3.5 & 5.0 & & & $\mathbf{R e}$ & etions & too slow & \\
\hline 9 & 1000 & nil & nil & & & & & & & & \\
\hline
\end{tabular}

The plots of $\mathrm{K}_{\mathrm{a}}$ against acidity and $\mathrm{K}_{\mathrm{b}}$ against basicity (Fig.1 and 2) are straight lines, which implies ${ }^{4}$ ) that both acidic and basic sites bring about the decomposition of $\mathrm{H}_{2} \mathrm{O}_{2}$. The sum of $\mathrm{K}_{\mathrm{a}}$ and $\mathrm{K}_{\mathrm{b}}$ is nearly equal to $\mathrm{K}$ for all catalysts except for binary oxides containing molybdena and tungstic oxide, where $K_{a}$ is nearly equal to $K$. This is because, these catalysts have no strong basic sites on their surface as is proved by the fact that they do not adsorb phenol and when poisoned with neutral red (pKa $\leqq$ +6.8 ) are unable to decompose $\mathrm{H}_{2} \mathrm{O}_{2}$.

It is also observed that $E_{a}$ and $E_{b}$ are inversely proportional to the acidity and basicity respectively ('Tables 1 and 2).

The above observations and our earlier work ${ }^{3}$ ) suggest that (i) acidic as well as basic sites bring about the decomposition of $\mathrm{H}_{2} \mathrm{O}_{2}$ and (ii) the mechanism of decomposition of $\mathrm{H}_{2} \mathrm{O}_{2}$ in presence of acidic and basic sites is

5) K. Gossner, R. Hite and D. Korner, Z. physik. Chem. [Frankfurt], 74, 67 (1971). 
Table 2 Decomposition of $\mathrm{H}_{2} \mathrm{O}_{2}$ in presence of various mixed oxide catalysts

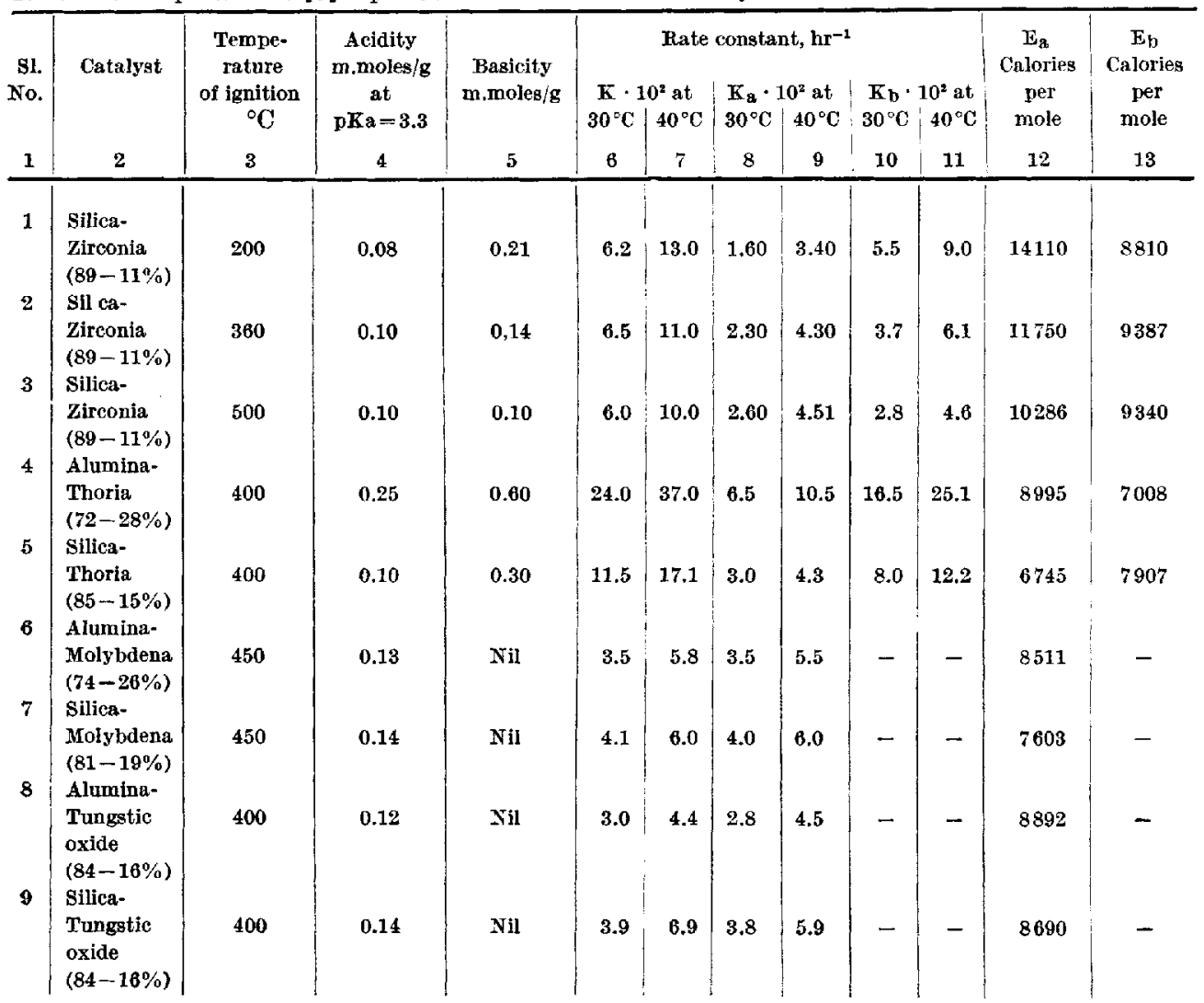

of a similar nature. On the basis of the observations made above the following mechanism is proposed for the decomposition of $\mathrm{H}_{2} \mathrm{O}_{2}$,

i) for acidic sites:

$$
\begin{aligned}
\mathrm{A}^{+}+\mathrm{H}_{2} \mathrm{O}_{2} & \rightarrow \mathrm{A}^{+} \mathrm{HO}_{2}^{-}+\mathrm{H}^{+} \\
\mathrm{A}^{+} \mathrm{HO}_{2}^{-}+\mathrm{H}_{2} \mathrm{O}_{2} & \rightarrow \mathrm{H}_{2} \mathrm{O}+\mathrm{O}_{2}+\mathrm{A}^{+} \mathrm{OH}^{-}
\end{aligned}
$$

ii) for basic sites:

$$
\begin{aligned}
\mathrm{B}^{-}+\mathrm{H}_{2} \mathrm{O}_{2} & \rightarrow \mathrm{B}^{-} \mathrm{H}^{+}+\mathrm{HO}_{2}^{-} \\
\mathrm{HO}_{2}+\mathrm{H}_{2} \mathrm{O}_{2} & \rightarrow \mathrm{H}_{2} \mathrm{O}+\mathrm{O}_{2}+\mathrm{OH}^{-} .
\end{aligned}
$$

In the above mechanism it is important to note that the mechanism is similar in both cases. The $\mathrm{HO}_{2}$ formed being responsible for the decomposition of $\mathrm{H}_{2} \mathrm{O}_{2}$.

Experiments tried with $\mathrm{TiO}_{2}$ which has acidity at $\mathrm{pKa}>+3.3$ and none at $\mathrm{pKa}=+3.3, \mathrm{Al}_{2} \mathrm{O}_{3}-\mathrm{SiO}_{2}$ which has acid strength of $\mathrm{pKa} \leqq-8.2$ 


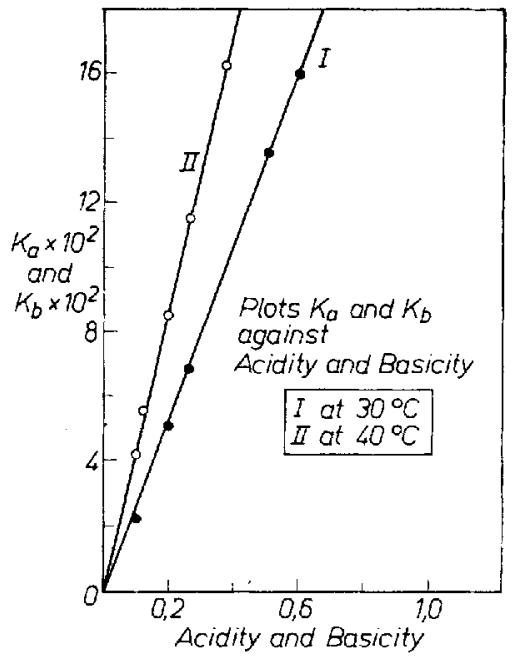

Fig. 1. The dependence of catalytic activity for decomposition of $\mathrm{H}_{2} \mathrm{O}_{2}$ on the number of acidic and basic centres of titania-zirconia catalyst

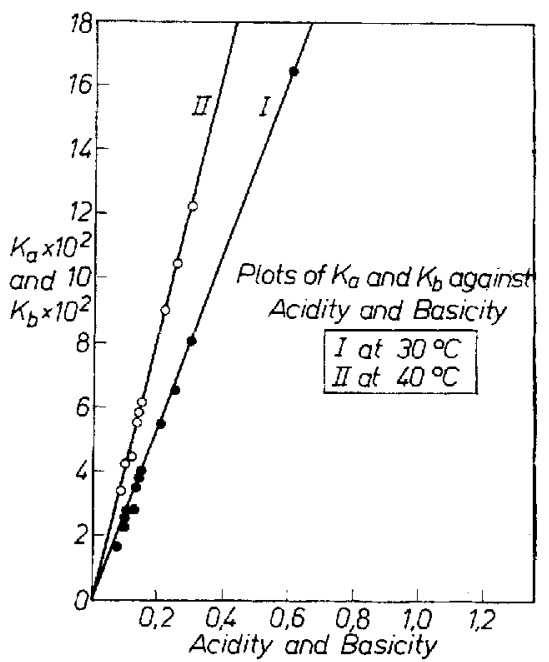

Fig. 2. The dependence of catalytic activity for decomposition of $\mathrm{H}_{2} \mathrm{O}_{2}$ on the number of acidic and basic centres of mixed-oxide catalysts (Table 2)

and $\mathrm{H}_{3} \mathrm{PO}_{4}$ supported on silica which has acid strength of $\mathrm{pKa} \leqq-5.7^{6}$ ) show that these catalysts are unable to decompose $\mathrm{H}_{2} \mathrm{O}_{2}$. It has been observed earlier that water poisons all acid sites of $\mathrm{pKa} \leqq-3.0^{7}$ ) and hence in aqueous solutions sites with acid strength of $\mathrm{pKa} \leqq-3.0$ are ineffective in the decomposition of $\mathrm{H}_{2} \mathrm{O}_{2}$ and sites with acid strength in the range with $\mathrm{pKa} \leqq+3.3$ and $\mathrm{pKa} \geqq-3.0$ are able to catalyse the decomposition of $\mathrm{H}_{2} \mathrm{O}_{2}$.

Both phenol and $\mathrm{H}_{2} \mathrm{O}_{2}$ have a pKa value in the range 9 to $11^{8}$ ). The basicity values of the surface of the catalysts measured by the phenol adsorption method should correlate well with the decomposition of $\mathrm{H}_{2} \mathrm{O}_{2}$, and it has been found to be so. Basic sites of $\mathrm{pKa} \geqq 10$ are able to decompose $\mathrm{H}_{2} \mathrm{O}_{2}$. Weaker sites are unable to do so as $\mathrm{H}_{2} \mathrm{O}_{2}$ having a pKa value in the range 9 to 11 needs stronger basie sites for it to react. This is proved by the fact that neutral red ( $\mathrm{pKa}=+6.8$ ) is unable to decompose $\mathrm{H}_{2} \mathrm{O}_{2}$.

Very strong acid sites on the surface of the catalyst either get poisoned by water ${ }^{7}$ ) or stabilise $\mathrm{H}_{2} \mathrm{O}_{2}$ by supplying $\mathrm{H}^{+}$ions as follows :

$$
\mathrm{HO}_{2}^{-}+\mathrm{H}^{+} \rightarrow \mathrm{H}_{2} \mathrm{O}_{2}
$$

6) H. A. Benesi, J. physic. Chem. 61, 970 (1957).

7) I. Matsuzaki and Y. FukUdA, J. Res. Inst. Catalysis, Hokkaido Univ. 17, 192 (1970).

8) F. A. Cotton and G. Wilkinson, "Advanced Inorganic Chemistry. A Comprehensive Text", p. 373, Interscience Publishers, London 1967. 
or the $\mathrm{HO}_{2}$ is very firmly held on the surface and is not available for the decomposition reaction. Acid sites of medium strength with $\mathrm{pKa} \leqq+3.3$ do not suffer from the above two drawbacks, they react with $\mathrm{H}_{2} \mathrm{O}_{2}$ and $\mathrm{HO}_{2}^{-}$ is adsorbed on the surface. Since the acid site is of medium sterngth the $\mathrm{HO}_{2}$ adsorbed on the surface is available for reaction with $\mathrm{H}_{2} \mathrm{O}_{2}$ as depcited in the mechanism discussed earlier.

Thus it is evident that basic sites of strength with $\mathrm{pKa}>10$ and acid sites in the range of $\mathrm{pKa}<+3.3$ and $>-3$ are catalytically active for the decomposition of $\mathrm{H}_{2} \mathrm{O}_{2}$ in aqueous solutions.

Acknowledgements. The authors wish to express their gratitude to the Bangalore University for the award of a Research scholarship to one of them (ABH) and to Dr. M. Shadaksharaswayi and Prof. T. D. Bhaskar for providing necessary facilities during the course of this work.

Bangalore-1 (India), Bangalore University, Central College, Department of Chemistry.

Bei der Redaktion eingegangen am 22. September 1972.

Anschr. d. Verf.: Dr. S. P. WALvekaR und Dr. A. B. HALGERI Central College, Department of Chemistry, Bangalore University, Bangalore-1 (India). 